\title{
Serviks kanseri ve HPV
}

\section{Cervical cancer and HPV}

\author{
Saadet Gonca Mavi Aydoğdu (), Ülkü Özsoy²
}

\section{öz}

Serviks kanseri, dünyada her iki dakikada bir kadının ölümüne neden olan ve kadınlarda meme kanserinden sonra en sık görülen ikinci kanserdir. Bugün servikal kanser gelişimi için HPV'nin mutlaka var olması gerektiği bilinmektedir ve serviks kanserlerinin çoğu $(\% 99,7)$ HPV ile ilişkilidir. Hastaların \%70'inde HPV-16 ve HPV-18 pozitiftir. Serviks kanseri, tarama testleri ile erken teşhis edilerek önlenebilen en önemli genital kanser türüdür. Ülkemizde de PAP (Papanicolau) smear, HPV DNA taraması gibi çeşitli yöntemlerle servikal kanser tarama programlarının geliştirilmesi ve taramaların toplumun geneline yayılması için çalışılmaktadır. Erken tanıda kullanılan PAP test kolay uygulanabilen, maliyeti düşük, zarar vermeyen, duyarlılığı yüksek, ayrıca tedavi yükünü, morbidite ve mortaliteyi azaltan bir testtir. HPV DNA testi, mevcut tüm servikal tarama testleri içerisinde en objektif ve tekrarlanabilir olanıdır. Servikal smear'ın sitolojik olarak değerlendirilmesi ve eş zamanlı HPV DNA çalışılması co-test olarak adlandırılmakta ve günümüzde 30 yaş üzerindeki kadınlarda en çok kabul gören tarama yöntemi olarak yerini almaktadır.

Anahtar Kelimeler: Co-test, HPV, HPV DNA testi, PAP smear, serviks kanseri

\section{Gíriș}

Tüm dünyada, y1lda 400.000'in üzerinde serviks kanseri olgusu görülmekte ve her yıl yaklaşık 250.000 hasta serviks kanserinden ölmektedir. ${ }^{[1]}$ Serviks kanseri, dünyada her iki dakikada bir kadın ölümüne neden olan ve kadınlarda meme kanserinden sonra en sık görülen ikinci kanserdir. Gelişmiş ülkelerde kadın kanserlerinin \%3,6'sını, gelişmemiş ülkelerde ise \%15'ini oluşturmaktadır. ${ }^{[2]}$ En sık 50-59

${ }^{7}$ Amasya Üniversitesi Sağlık Bilimleri Fakültesi, Ebelik Bölümü, Amasya ${ }^{2}$ Amasya Üniversitesi Sağlık Bilimleri Fakültesi, Ebelik Bölümü, Amasya

Yazışma Adresi / Correspondence:

Amasya Üniversitesi Sağlık Yüksekokulu İpekköy Yerleşkesi 05100 Amasya, Türkiye Tel. $\quad+905536356093$

E-mail: goncamavi38@gmail.com

Geliş / Received: $\quad 09.08 .2017$

Kabul / Accepted: 08.12.2017

\section{ABSTRACT}

Cervical cancer is the second most common in women after breast cancer, causing one of them to die every two minutes in the world. It is known that HPV must be present for the development of cervical cancer today, and most of the cervical cancers $(99.7 \%)$ are associated with it. HPV-16 and HPV-18 are positive in $70 \%$ of patients. Cervical cancer is the most important type of genital cancer that can be diagnosed and prevented in time by screening tests. In our country, various methods such as PAP (Papanicolau) smear and HPV DNA screening are being used to develop cervical cancer screening programs, and to spread the screening utility to the whole population. The PAP test used in early diagnosis is easy to perform, low cost, does not cause harm, is sensitive, and reduces treatment burden, morbidity and mortality. HPV DNA testing is the most objective and reproducible of all available cervical screening tests. Cytological evaluation of the cervical smear and concurrent HPV DNA study is called co-testing, and is now the most accepted screening method for women over 30 years of age.

Keywords: Cervical cancer, Co-test, HPV, HPV DNA testing, PAP smear

yaşları arasında görülmekle birlikte, ülkemiz koşullarında invaziv serviks kanserlerinin $\% 65^{\prime} \mathrm{i}, 40-60$ yaş grubunda görülmektedir. ${ }^{[3]}$

\section{Serviks kanseri-HPV ilișkisi}

Serviks kanserinin oluşumu için, insan papilloma virüsü (HPV) varlığı gereklidir, ancak yeterli değildir. ${ }^{[4]}$ Bugün, servikal kanser gelişimi için HPV'nin mutlaka var olması gerektiği, diğer risk faktörlerinin ya virüsle karşılaşma oranını arttırdığı ya da viral persistansın karsinojenik süreci hızlandırmada önemli olduğu konusu üzerinde durulmaktadır. ${ }^{[5]}$ Cinsel yönden aktif erişkinlerin \%70'inden fazlası, hayatlarının bir döneminde HPV'ye maruz kalmakta ve bunların da \%70'inden fazlasının 15-24 yaş arasında olduğu bildirilmektedir. ${ }^{[6]}$

HPV, kanserojen özelliklerine göre iki gruba ayrılır. Birinci grupta, "düşük riskli" olarak adlandırılan servikal lezyonlar 
ve genital siğillere neden olan HPV 6 ile 11 yer alır. İkinci grupta ise "yüksek riskli" olarak adlandırılan vajina, vulva, anüs, penis ve serviksin skuamöz kaynaklı karsinomuna neden olan HPV 16 ile 18 yer alır. ${ }^{[7,8]}$

İnsan papilloma virüsü, en sık cinsel yolla bulaşan hastalıktır ve serviks kanserlerinin çoğu (\%99,7) HPV ile ilişkilidir. ${ }^{[9]}$ Seksüel temastan sonra \%65 oranında enfeksiyon gelişir. ${ }^{[10]} \mathrm{HPV}$ ile enfekte olmayan kadınlarda servikste skuamöz hücreli karsinom gelişme riski düşük iken, enfekte olanlarda bu risk 250-400 kat artmaktadır. ${ }^{[4]}$ Genellikle cinsel aktivite sırasında anal bölge epitelinde meydana gelen travma sonucu, HPV bazal hücre tabakalarına yerleşir. Bazal hücreler çoğalır ve çekirdek içinde virüs replikasyonu gerçekleşir. Hücre daha iç kısımlara ilerledikçe, olgun virüs parçacıkları enfeksiyon halinde ortaya çıkar. ${ }^{[11]}$ Bariyer önlemler riski azaltır, ancak tam olarak koruyucu değildir. Cinsel yönden aktif kadınların \%70-80'i, genellikle seksüel aktivite başladıktan kısa süre sonra onkojenik HPV ile enfekte olur. Daha sonraki dönemdeki doğal enfeksiyon koruyuculuk sağlamaz. Bu nedenle, bir kişi yaşamı boyunca defalarca enfeksiyona yakalanabilir. ${ }^{[12]}$ Cinsel ilişki ile bulaşmada en önemli faktör, cinsel eş sayısı ve enfeksiyonun alındığı yaştır. Özellikle ilk cinsel ilişki yaşının erken olması, HPV enfeksiyonunda ve daha sonra gelişecek malign lezyonlar açısından oldukça önemlidir. ${ }^{[13]}$

\section{Serviks kanserinin belirtileri}

HPV enfeksiyonunun başlıca klinik aşamaları; latent, subklinik ve klinik dönemlerdir. Latent dönemde, hastalığın sitolojik ya da morfolojik hiçbir bulgusu yoktur; sadece ultrasensitif PCR teknikleri ile HPV DNA'sı gösterilebilir. [1] Genital kondilom ya da invaziv kanser gibi gözle görülebilen lezyonların ve belirtilerin bulunduğu dönem ise klinik dönemdir. ${ }^{[14]}$

Serviks kanserinin en tipik bulgusu ağrısız kanama ve et suyu renginde vajinal akıntıdır. Anormal vajinal kanama, postkoital veya postmenopozal kanama, periyodlar arası lekelenmeler, adet kanamalarının uzun sürmesi ve normalden daha ağır geçmesi, pelvik muayene sonrası kanama, disparoni, ileri evrelerde kötü kokulu vajinal akıntı, bel ve kasık ağrısı, genital ve anal mukozalarda karnabahar görünümünde tek veya çok sayıda olabilen ağrısız lezyonlar, anemi, kilo kaybı, idrar yapmada güçlük ya da bacak ödemi görülebilir. ${ }^{[4,13,15]}$

Bimanuel muayenede enfekte doku sert olarak ele gelir ve girintili çıkıntılı, pürtüklü hissedilir. Serviksin intraepitelyal lezyonlarının ve erken evre kanserinin erken tanısı, sitolojik ve kolposkopik muayeneler ile mümkündür ${ }^{[11,16]}$

\section{Serviks kanserinde tarama}

Taramanın birincil hedefi, servikal kanseri önleme amacıyla, serviksin intraepitelyal prekürsör lezyonlarının doğru tespit edilmesi ve tedavisinin zamanında yapılmasıdır. ${ }^{[17]}$ Serviks kanserinin uzun preinvaziv döneme sahip olması, etkinliği kanıtlanmış sitolojik tarama testlerinin varlığı, preinvaziv lezyonların etkili bir şekilde tedavi edilebilir olması bu hastalığa özgü önemli bir özellik olup, tarama ve erken tanıya imkan sağlar. ${ }^{[18]}$ Böylece, daha çok hasta preinvaziv evrede teşhis edilebilmekte ve sağ kalım oranları yükseltilebilmektedir. ${ }^{[19]}$ Servikal kanser tarama programları, bu kanserin görülme sıklığını ve ölüm oranlarını azaltmak için son derece önemlidir. Ülkemizde de PAP (Papanicolau) smear, HPV DNA taraması gibi çeşitli yöntemlerle servikal kanser tarama programlarının geliştirilmesi ve taramaların toplumun geneline yayılması için çalışılmaktadır. ${ }^{[20]}$

PAP smear; serviks ve vajen epitelinden dökülen normal hücreler ve hastalık nedeni ile değişmiş hücrelerin incelenmesine dayanan bir testtir. ${ }^{[21]}$ PAP smear testi ile preinvaziv ve kanseröz dönemdeki hücreler endoservikal kanalda saptanmakta ve bu aşamadaki kanser tedavisi ile, hücreler kansere dönüşmeden kanser gelişimi önlenebilmektedir.

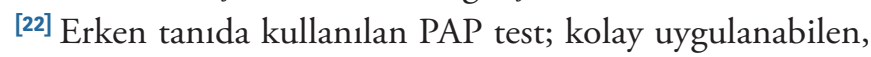
maliyeti düşük, zarar vermeyen, duyarlılığı yüksek, ayrıca tedavi yükünü, morbidite ve mortaliteyi azaltan bir testtir.

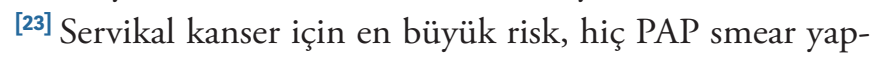
tırmamış olmaktır. Böyle bir kadında, yaşam boyu serviks kanserine yakalanma riski $1 / 100$ 'dür. Tek bir negatif PAP smear, kanser riskini \%45 oranında, yaşam boyu alınmış dokuz adet negatif PAP smear ise bu riski \%99 oranında azaltmaktadır. ${ }^{[24]}$ Türkiye Sağlık Bakanlığı Kanserle Savaş Dairesi Başkanlığı tarafindan hazırlanan ve 2009-2015 yıllarını kapsayan kanser tarama programında, serviks kanseri ulusal tarama programına alınmıştır. ${ }^{[19]}$ Serviks Kanseri Ulusal Tarama Standartlarına göre: 35-40 yaş aralığındaki tüm kadınlardan en az bir kez smear alınması; sonrasında beş yıllık aralıklarla tekrarlanması ve son üç testi negatif olan 65 yaşındaki kadınlarda taramaya son verilmesi; CIN II/III nedeniyle histerektomize olmuş olgularda üç adet dokümante edilebilen, teknik olarak yeterli negatif sitoloji ve son 10 yılda anormal/pozitif sitoloji yokluğunda taramanın kesilmesi; HIV enfeksiyonu olanlar / immünosupresif tedavi alan olgularda ilk yıl iki kez, sonuçları negatifse yılda bir kez alınması öngörülmüştür. ${ }^{[4,19,25,26]}$

Serviks kanserinin erken tanı ve taramasında bir diğer önemli yöntem de HPV DNA testidir. Mevcut tüm servikal tarama testleri içerisinde, HPV testi en objektif ve tekrarlanabilir olanıdır. HPV DNA testinin serviks kanseri ile ilişkisi artık kanıtlanmış olup, serviks kanserli hastaların \%99,9'unda 
HPV DNA varlığı gösterilmiştir. ${ }^{[27]}$ Son yıllarda geliştirilen HPV DNA testinin sitolojik veya diğer bilinen tarama yöntemlerine göre daha duyarlı olduğu gösterilmiştir. ${ }^{[28]}$

Servikal smear'n sitolojik olarak değerlendirilmesi ve aynı örnekte eş zamanlı HPV DNA çalışılması "co-test" olarak adlandırılır. Co-test, günümüzde 30 yaş üzerindeki kadınlar için en çok kabul gören tarama yöntemidir. ASCCP (American Society of Colposcopy and Cervical Pathology) ve ACOG (American College of Obstetricians and Gynecologists), 30-65 yaş arasında kadınların beş yılda bir co-test ile taranmasını önermektedir. ${ }^{[29-32]}$ Otuz yaş alındakilerde ise HPV enfeksiyonları yüksek oranda geçici olduğundan, bu yaş grubuna co-test önerilmemektedir; persistansı düşüktür ve testin yanlış pozitiflik oranını arttırır. Bu nedenle, 21-30 yaş arasında üç yılda bir sadece sitoloji ile tarama önerilmektedir. ${ }^{[33]}$

\section{Korunma yolları}

Serviks kanseri, tarama testi ile erken teşhis edilerek önlenebilen en önemli jinekolojik kanser türüdür. Bu nedenle serviks kanserinden korunmada alınacak önlemler açısından, kansere neden olduğu düşünülen faktörlerin bilinmesi önemlidir. ${ }^{[34]}$ Korunmada, düşük riskli hastalar için ayrıntılı anamnez almak ve sonrasında tarama kurallarını izlemek yeterlidir. Orta risk altındaki hastalar için, daha önceki anormal test sonuçları, displazi, immünsupresyon veya kanser gibi yüksek risk durumlarının belirlenmesi ve sonrasında koruyucu önlemlerin alınması gerekir. ${ }^{[35]}$ Primer korunmada profilaktik aşı uygulaması yer alırken; günümüzde uygulanan, tarama testleri ile HPV'yi erken dönemde belirleyip, sebep olduğu lezyonları erken tedavi ederek invaziv kanser gelişmesini önleyen sekonder korunmadır. ${ }^{[18]}$ Profilaktik HPV aşısı yeni bir enfeksiyon gelişimini önler, fakat vücutta var olan enfeksiyonu tedavi etmez. ${ }^{[17]}$ Kişinin cinsel yönden aktif olmadığı 9-13 yaş döneminde, aşı uygulamasıyla yüksek düzeyde koruma sağlanır. ${ }^{[8,14]} \mathrm{HPV}$ enfeksiyonunu önlemek için, en yaygın onkojenik HPV alt tipleri olan 6, 11, 16 ve 18 'i içeren farklı HPV aşıları bulunmaktadır ve bu aşılar serviks kanserlerinin \%15'ine karşı koruma sağlar. [36] $\mathrm{Bu}$ amaçla geliştirilen bivalan ve kuadrivalan HPV aşıları, hem kadınlarda hem de erkeklerde kullanılmaktadır. Bivalan aşı HPV 16 ve 18'e, kuadrivalan aşı ise HPV 6, 11, 16 ve 18 'e karşı etkilidir. Gardasil ve Cervarix, FDA (U.S. Food and Drug Administration) tarafindan kabul edilen koruyucu aşılardandır. Gardasil veya Cervarix’in servikal kanserden koruyuculuğu için süre, şimdilik en az beş yıl olarak bildirilmektedir. ${ }^{[37]}$ Gardasil, HPV 6, 11, 16 ve 18 ile ilişkili olan CIN II/III lezyonlarından korunmada bu HPV tipleri açısından riskli olan kadınlarda \%100 sonuç vermektedir.
Bunun da ötesinde, siğilleri de içeren vulvar lezyonlardan korunma noktasında da aşının verimliliği \%100'e yakındır. ${ }^{[38,39]} \mathrm{HPV}$ aşısı, henüz Türkiye ulusal aşı takviminde yer almamaktadır; uygulanması tamamen ailenin isteğine bağlıdır ve ücretlidir. ${ }^{[40]}$

Sağlık personelleri, kadınlara bilgi verirken, aşının sadece HPV'nin belirli tiplerine karşı koruyucu olduğu, tüm tiplerden korumayı içermediği, cinsel yolla bulaşan diğer hastalıklara karşı bir koruma sağlamadığı, aşı olmanın PAP smear taraması yaptırma gerekliliğini ortadan kaldırmadığı ve düzenli jinekolojik muayeneye gelmenin her zaman gerekli olduğunu vurgulamalıdır. ${ }^{[4]]}$

HPV enfeksiyonu ile karşılaşma riskini azaltmak için uygulanması gereken diğer birincil önleme stratejileri; bireylere cinsel başlangıçlarını geciktirmeyi, ömür boyu cinsel partner sayısını azaltmayı ve kondom kullanımını arttırmayı içerir. ${ }^{[8]} \mathrm{HPV}$ aşısının ve servikal taramanın teşvikinde tüm sağlık profesyonelleri kilit rol oynar. ${ }^{[42]}$

\section{SONUC,}

Serviks kanseri risk faktörlerinin saptanması, risk faktörlerine ilişkin bireylere eğitim ve danışmanlık yapılmasında, eğitimli sağlık profesyonellerine önemli görevler düşmektedir. ${ }^{[43]}$ Serviks kanserinden korunmada, özellikle birinci basamak sağlık hizmetlerinde çalışan sağlık personelleri, hizmet ettikleri toplumdaki kadınların farkında olma düzeylerinin arttırılmasında ve erken tanıya yönlendirilmesinde aktif rol almalıdır. ${ }^{[4]}$ Üreme çağındaki servikal kanser hastaları ile doğurganlık ve cinsellik ile ilgili konularda, beklentilerin ve yaşam kalitesinin şekillendirilmesine yardımcı olmak için etkili iletişim kurulmalıdır. ${ }^{[8]}$

\section{Hakem Değerlendirmesi \\ Dış bağımsız \\ Çıkar Çatışması \\ Yazarlar çıkar çatışması olmadığını beyan etmişlerdir. \\ Finansal Destek \\ Herhangi bir mali destek alınmamıştır.}

\section{Peer-review}

Externally peer-reviewed.

Conflict of Interest

No conflict of interest was declared by the authors.

Financial Disclosure

No financial disclosure was received.

\section{KAYNAKLAR}

1. Tekbaş S. Jinekolojik kanser hastalarına yaşam kalitesi ve tedavibakımın etkileri. Doktora Tezi. Edirne: Trakya Üniversitesi Sağlık Bilimleri Enstitüsü, Hemşirelik Anabilim Dalı; 2014.

2. Ege S. Gebe Kadınlarda Human Papilloma Virüs sıklığının araştırılması. Tıpta Uzmanlık Tezi. Zonguldak: Bülent Ecevit Üniversitesi Tıp Fakültesi, Kadın Hastalıkları ve Doğum Anabilim Dalı; 2014. 
3. T. C. Sağlık Bakanlığı Sağlık İstatistikleri Yıllı̆̆1 2015. Yayın No:1054. Ankara: Sistem Ofset Basım Yayın; 2016. ss.36-7.

4. Aref-Adib M, Freeman-Wang T. Cervical cancer prevention and screening: the role of human papillomavirus testing. The Obstet Gynaecol 2016;18:251-63. https://doi.org/10.1111/tog.12279

5. Eroğlu C, Keşli R, Eryılmaz MA, Ünlü Y, Gönenç O, Çelik Ç. Serviks kanseri için riski olan kadınlarda HPV tiplendirmesi ve HPV sıklığının risk faktörleri ve servikal smearle ilişkisi. Nobel Med 2011;7:72-7.

6. Sonay Kurt A, Canbulat N, Savaşer S. Adölesan dönem cinselliğiyle öne çıkan serviks kanseri ve risk faktörleri. Bakırköy Tıp Dergisi 2013;9:59-63. https://doi.org/10.5350/BTDMJB201309204

7. Alkış Koçtürk S. Menopoz öncesi ve sonrası kadınlarda insan papilloma virüs (HPV) DNA'sının araştırılması. Uzmanlık Tezi. Kahramanmaraş: Kahramanmaraş Sütçü İmam Üniversitesi Tip Fakültesi, Tıbbi Mikrobiyoloji Anabilim Dalı; 2010.

8. Finocchario-Kessler S, Wexler C, Maloba M, Mabachi N, Ndikum-Moffor F, Bukusi E. Cervical cancer prevention and treatment research in Africa: a systematic review from a public health perspective. BMC Womens Health 2016;16:29. https://doi. org/10.1186/s12905-016-0306-6

9. Öztürker C, Sönmez G. Endometrium ve serviks kanserlerinde görüntüleme. TRD Sem 2015;3:1-11. https://doi.org/10.5152/ trs. 2015.158

10. Erdemir F. Human papilloma virüs (HPV) ve erkek cinsel sağlığı. Androloji Bülteni 2014;59:217-21.

11. Taşkın L. Doğum ve Kadın Sağlığı Hemşireliği. Ankara: Sistem Ofset Matbaacilık; 2012. ss.43-67.

12. Ceyhan M. Human papillomavirus (HPV) aşıları. Klinik Gelişim Dergisi 2012;25:36-9.

13. Alp Avcı G, Bozdayı G. İnsan papilloma virüsü. Kafkas J Med Sci 2013;3:136-44. https://doi.org/10.5505/kjms.2013.52724

14. Öztürk D. Bir Üniversitenin Sağılıkla İlgili Alanlarında Öğrenim Gören Gençlerin Human Papilloma Virüs Enfeksiyonu İlişkin Bilgileri. Yüksek Lisans Tezi. Ankara: Hacettepe Üniversitesi Sağlık Bilimleri Enstitüsü, Doğum ve Kadın Hastalıkları Hemşireliği Programı, 2012.

15. Karaoğlan D. Kadınların serviks kanseri risk faktörleri ve erken tanı yöntemlerine ilişkin bilgi ve uygulamalarının belirlenmesi. Yüksek Lisans Tezi. Lefkoşa, K.K.T.C.: Yakın Doğu Üniversitesi, Sağlık Bilimleri Enstitüsü, Hemşirelik Programı; 2016.

16. Sevil Ü, Ertem G. Perinatoloji ve Bakım. Ankara: Nobel Tip Kitabevleri; 2016.

17. Jeronimo J, Castle PE, Temin S, Denny L, Gupta V, Kim JJ, et al. Secondary prevention of cervical cancer: ASCO Resource-Stratified Clinical Practice Guideline. J Glob Oncol 2017;3:635-57.

18. Yıldırımer N. Levonorgestrel-releasing intrauterin sistem ve bakırlı rahim içi araçların kullanım süresi ile servikal sitoloji değerlendirilmesi. Tıpta Uzmanlık Tezi. Düzce: Düzce Üniversitesi Tıp Fakültesi, Kadın Hastalıkları ve Doğum Anabilim Dalı; 2012.

19. Demirel G, Gölbaşı Z. Kadın sağlığı taramasında güncel durum. Gümüşhane Üniversitesi Sağlık Bilimleri Dergisi 2015;4:638-59.

20. Yüksel KB, Şencan H, Kabil Kucur S, Gözükara İ, Seven A, Polat M, Keskin N. Human papilloma virus (HPV) enfeksiyonu ve HPV aşısı hakkında bilgi düzeyi ve genel eğilimler; Dumlupınar Üniversitesi-Evliya Çelebi Eğitim ve Araştırma Hastanesi'ndeki doktor, hemşire ve sağlık personellerini içeren anket taraması. Jinekoloji-Obstetrik ve Neonatoloji Tip Dergisi 2015;12:64-7.

21. Durusoy EE. Preinvaziv ve invaziv servikal lezyonlarda Human Papillomavirus tiplerinin prevalansının saptanması. Uzmanlık Tezi. Bursa: Uludağ Üniversitesi Tıp Fakültesi, Kadın Hastalıkları ve Doğum Anabilim Dalı; 2014.
22. Demirgöz Bal M. Kadınların PAP smear testi yaptırma durumlarının sağlık inanç modeli ölçeği ile değerlendirilmesi. Marmara Üniversitesi Sağlık Bilimleri Enstitüsü Dergisi 2014;4:133-8. https://doi.org/10.5455/musbed.20140711031132

23. Özdemir Ö, Bilgili N. Bir eğitim hastanesinde çalışan hemşirelerin meme ve serviks kanserlerinin erken tanısındaki bilgi ve uygulamaları. TAF Prev Med Bull 2010;9:605-12. https://doi. org/10.5455/pmb.20100427030359

24. Kög İ, Turan T, Karabük E, Karayünlü B, Özgül N, Demir ÖF, et al. Etlik KETEM grubunun serviks ve meme kanseri tarama programı sonuçları. TAF Prev Med Bull 2012;11:145-52. https:// doi.org/10.5455/pmb.20110812120702

25. Sönmez Y, Nayir T, Köse S, Gökçe B, Kişioğlu AN. Bir sağlık ocağı bölgesinde 20 yaş ve üzeri kadınların meme ve serviks kanseri erken tanısına ilişkin davranışları. S.D.Ü. Tıp Fak Derg 2012;19:124-30.

26. Tuncer M, editör. T. C. Sağlık Bakanlığı Kanserle Savaş Dairesi Başkanlığı. Ulusal Kanser Programı 2009-2015. Erişim Adresi: http://www.ssuk.org.tr/eski_site_verileri/pdf/Ulusal_Kanser_ Kontrol_Programi_2009-2015.pdf Erişim Tarihi: 15.10.17.

27. Baran M. Meme ve serviks kanseri konusunda kadınların bilgi ve bilinç düzeyleri (Diyarbakır İl Merkezi Örneği). Yüksek Lisans Tezi. İstanbul: Beykent Üniversitesi Sosyal Bilimler Enstitüsü, İ̧letme Yönetimi Anabilim Dalı, Hastane ve Sağlık Kurumları Yönetimi Bilim Dalı; 2013.

28. Örenli G. İlköğretim ikinci kademede öğrenim gören kız öğrencilerin annelerinin rahim ağzı kanseri ve HPV aşısı konusunda bilgi tutum davranışları. Yüksek Lisans Tezi. Zonguldak: Bülent Ecevit Üniversitesi Sağlık Bilimleri Enstitüsü, Halk Sağlığı Anabilim Dalı; 2015.

29. Yıldırım D. Gökaslan H. Serviks kanseri taramasında HPV DNA testinin yeri. Türk Jinekolojik Onkoloji Dergisi 2015;1:1-6.

30. Saslow D, Solomon D, Lawson HW, Killackey M, Kulasingam S, Cain J, et al. American Cancer Society, American Society for Colposcopy and Cervical Pathology, and American Society for Clinical Pathology Screening Guidelines for the Prevention and Early Detection of Cervical Cancer. CA Cancer J Clin 2012;62:147-72. https://doi.org/10.3322/caac.21139

31. Committee on Practice Bulletins-Gynecology. ACOG Practice Bulletin Number 131: Screening for cervical cancer. Obstet Gynecol 2012;120:1222-38. https://doi.org/10.1097/ AOG.0b013e318277c92a

32. Katki HA, Kinney WK, Fetterman B, Lorey T, Poitras NE, Cheung L, et al. Cervical cancer risk for women undergoing concurrent testing for human papillomavirus and cervical cytology: a population-based study in routine clinical practice. Lancet Oncol 2011;12:663-72. https://doi.org/10.1016/S14702045(11)70145-0

33. Gökgöz N, Aktaş D. Kadınların serviks kanseri ve PAP smear testi yaptırma durumlarına yönelik farkındalık düzeylerinin belirlenmesi. Yıldırım Beyazıt Üniversitesi Sağlık Bilimleri Fakültesi Hemşirelik E-Dergisi 2015;3:11-23.

34. Çeşmeci Y, Köylü B, Sulaiman J, Sancak E, Şenel S, Ertuğ Baki $\mathrm{H}$ ve ark. İnternlerin gözünden HPV enfeksiyonları ve HPV aşısı. Türk Jinekolojik Onkoloji Dergisi 2015;3:85-92.

35. Perkins RB, Cain JM, Feldman S. Using risk stratification to reduce medical errors in cervical cancer prevention. JAMA Intern Med 2017;177:1411-2. https://doi.org/10.1001/ jamainternmed.2017.3999

36. Committee On Practice Bulletins. Cervical cancer screening and prevention. The American College of Obstetricians and Gynecologists, Practice Bulletin; 2017. 
37. Ozan H, Çetinkaya Demir B, Atik Y, Gümüş E, Özerkan K. Kadın hastalıkları ve doğum polikliniğine başvuran hastaların Human Papilloma Virüs ve HPV aşısı hakkındaki bilgi düzeylerinin belirlenmesi. Uludăg Üniversitesi Tip Fakültesi Dergisi 2011;37:145-8.

38. Garland SM, Hernandez-Avila M, Wheeler CM, Perez G, Harper DM, Leodolter S, et al. Quadrivalent vaccine against humanpapillomavirus to prevent anogenital diseases. N Engl J Med 2007;356:1928-43. https://doi.org/10.1056/NEJMoa061760

39. Qian J, Dong Y, Pang YY, Ibrahim R, Berzofsky JA, Schiller JT, Khleif SN. Combined prophylactic and therapeutic cancer vaccine: enhancing CTL responses to HPV16 E2 using a chmeric VLP in HLA-A2 mice. Int J Cancer 2006;118:3022-9. https:// doi.org/10.1002/ijc.21781

40. Yıldırım D. Bölgemizde servikal kanser ve prekanseröz lezyonları olan kadınlarda onkojenik Human Papillomavirus genotiplerinin prevalansının belirlenmesi. Yüksek Lisans Tezi. Adana: Çukurova Üniversitesi, Sağlık Bilimleri Enstitüsü, Mikrobiyoloji Anabilim Dalı; 2010
41. Pınar G, Topuz Ş, An Ş, Doğan N, Kaya N, Algıer L. Başkent Üniversitesi Ankara hastanesi kadın hastalıkları ve doğum polikliniğine başvuran kadınların HPV aşısı ve serviks kanseri ile ilgili bilgi düzeyleri. Türk Jinekolojik Onkoloji Dergisi 2010;1:11-8.

42. Powles C. HPV vaccine: a key cervical cancer prevention strategy: Primary HPV vaccination and secondary cervical screening are effective prevention strategies to reduce the incidence and mortality of cervical cancer in Ireland. Women's Health 2017; 25(4). 57-58.

43. Kanbur A, Çapık C. Servikal kanserden korunma, erken tanıtarama yöntemleri ve ebe/hemşirenin rolü. Sağlık Bilimleri Fakültesi Hemşirelik Dergisi 2011;61-72.

44. Dönmez A. HPV (+) kadınlarda sağlıklı yaşam biçimi davranışları geliştirmenin serviks kanserini önlemeye etkisi. Yüksek Lisans Tezi. İzmir: Ege Üniversitesi, Sağlık Bilimleri Enstitüsü, Ebelik Anabilim Dalı; 2013. 